\title{
PERSPEKTIF NILAI PESANTREN: PENGEMBANGAN KUALITAS PRIBADI IDEAL KONSELOR
}

\author{
Ishlakhatus Sa'idah ${ }^{1} \&$ Moh. Ziyadul Haq Annajih ${ }^{2}$, \\ ${ }^{1}$ IAIN Madura; ${ }^{2}$ STAI Miftahul Ulum Pamekasan \\ Email: ishlakhatus.saidah@gmail.com. \\ Email: najihas@gmail.com.
}

\begin{abstract}
The personal quality of the counselor is very supportive of the process and results of counseling activities. However, in practice there are still often some problems related to the counselor's personal, although there have been many expert formulations about the personal qualities of the counselor. This is due to the standards used in the formulation of the personal qualities of the Western formula counselors that are not in accordance with the sociopsychological conditions of the Indonesian people. So it is important to attempt to internalize the values of local wisdom into the formulation of the personal qualities of the counselor. One approach that can be used is a formula that is explored from the values of pesantren. The aim of the study is to develop the personal qualities of counselors based on the values of pesantren. This study uses a library study approach. The values of boarding schools that can be extracted into the formulation of the ideal personal qualities of the counselor include, (1) sincerity, (2) patience, (3) firm and respectful, (4) caution, (5) openness, (6) pious, (7) compassion, and (8) fair.
\end{abstract}

Keywords: Personal Counselor, Pesantren

\section{Pendahuluan}

Terdapat tiga hal penting terkait kualitas yang harus dimiliki konselor, yaitu pengetahuan, keterampilan, dan kepribadian. Meskipun ketiga hal tersebut satu kesatuan yang tidak dapat dipisahkan. Tanpa mengesampingkan aspek lainnya, aspek kepribadian konselor merupakan hal penting yang dapat menunjang keberhasilan dalam layanan bimbingan dan konseling. Hal tersebut selaras sebagaimana dalam salinan Permendiknas No. 27 Tahun 2008 tentang Standar Kualifikasi Akdemik dan Profesional Konselor bahwa kinerja konselor yang dilandasi oleh sikap, nilai, dan kecendrungan pribadi menegaskan bahwa landasan profesionalitas konselor lebih dominan dipengaruhi oleh aspek kepribadian pada diri konselor.

Salinan Permendiknas di atas menegaskan bahwa konselor dengan pribadinya memiliki peranan yang sangat berpengaruh terhadap keefektifan 
layanan bimbingan dan konseling. Dalam hal ini, pribadi konselor menjadi kunci penentu keberhasilan layanan bimbingan dan konseling. Selanjutnya, Corey merumuskan tentang kualitas pribadi konselor yang ideal yaitu, konselor yang ideal memiliki sebuah identitas, menghormati dan menghargai dirinya dan konselinya, bersikap terbuka untuk suatu perubahan, mampu membuat pilihan yang berorientasi hidup, bersikap otentik, tulus, dan jujur, memiliki rasa humor, mampu menghargai pengaruh budaya, memiliki minat yang tulus untuk mensejahterakan orang lain, memiliki keterampilan interpersonal yang efektif, memiliki minat, serta mampu mempertahankan batas-batas yang sehat. ${ }^{1}$

Keberhasilan layanan bimbingan dan konseling lebih tergantung pada kualitas pribadi dibandingkan penguasaan teknik yang dimiliki oleh konselor. Dalam hal ini, "alat" yang terpenting untuk digunakan oleh konselor adalah dirinya sendiri sebagai pribadi. ${ }^{2}$ Konselor sebagai alat yang terpenting dalam layanan bimbingan dan konseling sehingga keberadaanya sebagai pribadi yang tercermin melalui sikap dan perilakunya sangat menentukan keberhasilan layanan bimbingan dan konseling. Keselarasan sikap dan perilaku merupakan salah satu indikator sikap profesional konselor. Sikap profesional setidaknya menghadirkan sikap yang empati, menghargai, toleransi, kejujuran, religius, dan lainnya.

Potret kualitas pribadi konselor merupakan dimensi yang sangat krusial keberadaaannya dalam layanan bimbingan dan konseling. Krusial karena standar-standar yang ada belum terinternalisasikan menjadi diri. ${ }^{3}$ Namun, dalam praktiknya masih sering ditemui beberapa permasalahan yang berkaitan dengan pribadi konselor, meskipun sudah banyak rumusan para ahli tentang kualitas pribadi ideal konselor. Hal ini disebabkan oleh (1) standar yang turun dari rumusan kualitas pribadi konselor ideal rumusan Barat yang belum tentu sesuai dengan kondisi sosio-psikis masyarakat Indonesia, (2) rumusan standar kualitas pribadi lebih bersifat top-down dalam naungan legalitas politis, bukan buttom-up sebagaimana keinginan dan godwill konselor sendiri, dan (3) rumusan standar kualitas pribadi konselor yang kompleks dengan tanpa basis riset di Indonesia, khususnya. ${ }^{4}$

${ }^{1}$ G. Corey, Theory and Practice of Counseling and Psychotherapy (Buku Terjemahan). (Belmont, CA: Brooks/Cole, 2009), 128

2 MZH. Annajih, Karakteristik Pribadi Ideal Konselor dalam Perspektif Aswaja an-Nahdliyah (Kajian Hermeneutik Gadamer Terbadap Teks Khittah an-Nabdliyah). (Tesis Pascasarjana Univ. Nageri Malang, 2016), 14-15

${ }^{3}$ Mappiare AT, "Martabat Konselor Indonesia dalam Falsafab dan Kinerja Model KIPAS: Konseling Intensif Progresif Adaptif Struktur", (Prosiding Kongres XII, Konvensi Nasional XVII ABKIN dan Seminar Internasional Konseling. Bali, 14-16 November 2013), hal. 40

${ }^{4}$ Mappiare AT, "Martabat Konselor Indonesia dalam Falsafab dan Kinerja Model KIPAS: Konseling Intensif Progresif Adaptif Struktur,.... 40 
Penjelasan Mappiare AT di atas memberikan ruang kepada para peneliti dan praktisi konseling untuk melakukan upaya internalisasi ke dalam nilai-nilai kearifan lokal (local wisdom) dalam merumuskan konsepsi kualitas pribadi konselor. Salah satu pendekatan yang dapat digunakan untuk merumuskan kualitas pribadi konselor berbasis kearifan lokal adalah rumusan kualitas pribadi konselor yang digali dari nilai-nilai pesantren, sebab pesantren merupakan lembaga pendidikan tertua dan dianggap sebagai produk asli Indonesia yang mengandung nilai-nilai keislaman dan sarat dengan nilai-nilai lokalitas keindonesiaan. $^{5}$

Pendidikan pesantren berbeda dengan pendidikan di luar pesantren. Pendidikan di pesantren memiliki karakter khas yang tercermin pada proses pendidikan di pesantren yang diselenggarakan dalam waktu 24 jam. Mulai dari pendidikan formal sampai pendidikan non-formal yang berlangsung sepanjang waktu. Rujukan pendidikan pesantren berlandaskan pada pemahaman Aswaja (ablu sunnah wal jamaab) sebagai ajaran keislaman yang dianut oleh mayoritas masyarakat Indonesia. ${ }^{6}$ Oleh karena itu, nilai-nilai pesantren di dalamnya merujuk kepada para tokoh (imam) Aswaja sebagai prinsip yang mendasarinya. Misalnya, dalam Fiqh menganut Syafi'iyah, Tauhid menganut Asyariah dan Maturidiah, dan Tasawuf menganut pemikiran al-Ghazali.

Selain diajarkan tentang syariat dan ketauhidan, pendidikan pesantren juga mengajarkan akhlak (etika) yang tidak kalah pentingnya. Pembelajaran akhlak yang diterapkan di pesantren tentunya tidak lepas dengan nilai-nilai yang terkandung dalam ajaran Aswaja, sehingga acuan yang digunakan dalam pembelajaran akhlak di pesantren, baik pendidikan formal maupun non formal merujuk kepada para tokoh di kalangan Aswaja, seperti Syaikh Az-Zarnuji, KH. Hasyim Asyari, Al-Ghazali, dan lainnya. Maka perlu kiranya mempertimbangkan pelaksanaan bimbingan dan konseling yang sesuai dengan standar dan nilai-nilai pesantren. Konselor dituntut untuk meningkatkan kualitas hubungan dalam konseling dengan cara menerapkan teknik-teknik konseling dan kualitas pribadinya. Bagi konselor di pesantren kualitas pribadi konselor tersebut selayaknya mengandung nilai-nilai pesantren. ${ }^{7}$ Oleh karena

\footnotetext{
${ }^{5}$ MI. Usman, Pesantren Sebagai Lembaga Pendidikan Islam (Sejarah Labir, Sistem Pendidikan, dan Perkembangannya Masa Kini). Vol. XIV Nomor 1 (Jurnal Al Hikmah, 2013), 101.

${ }^{6}$ Aswaja an-Nahdliyah merupakan firqah (kelompok) Islam tradisional Indonesia sekaligus kelompok mayoritas dengan populasi sebanyak 91,2 juta atau 36\% dari populasi 257 juta penduduk Indonesia yang mempunyai hak pilih, bahkan populasi riil di lapangan diasumikan bisa melebih angka survei yang dikeluarkan oleh Badan Pusat Statistik. Lihat: MZH. Annajih Karakteristik. Pribadi Ideal Konselor dalam Perspektif Aswaja an-Nabdliyah (Kajian Hermeneutik. Gadamer Terbadap Teks Khittah an-Nahdliyah). (Tesis Pascasarjana Univ. Nageri Malang, 2016), 3.

7 Arifin, S. Potret Kualitas Pribadi Konselor Bermartabat Perspektif Konseling At-Tawazun. (Prosiding Kongres XII, Konvensi Nasional XVIII ABKIN dan Seminar Internasional Konseling. Bali, 14-16 2013), 280.
} 
itu, penelitian ini bertujuan untuk mengembangkan kualitas pribadi konselor yang berdasar pada nilai-nilai pesantren. Penelitian ini menggunakan penelitian kualitatif dalam bentuk kajian kepustakaan (library research) yang bertujuan untuk menelusuri dan menginterpretasi literatur-literatur dalam bentuk buku, artikel jurnal akademik, hasil penelitian, dan sumber kepustakaan relevan lainnya sebagai bahan pustaka dan data penelitian yang terkait dengan kajian yang dibahas. ${ }^{8}$ Sumber data dalam penelitian ini dibagi menjadi dua, yaitu data primer dan sekunder. Data primer yang digunakan adalah Ayyubal Walad karya AlGhazali, ta'lim al-muta'allim karya Syaikh Az-Zarnuji dan adabu al-Alim wa alMuta'allim karya KH. Hasyim Asyari. Sedangkan data sekunder yang digunakan adalah wawancara bersama para ahli serta dokumentasi lain yang berkaitan dengan kajian yang dibahas. Teknik pengumpulan data yang digunakan adalah menggunakan teknik dokumentasi, yakni dengan mengambil data dari karya AlGhazali, Syaikh Az-Zarnuji, dan KH. Hasyim Asyari. Kemudian, pengambilan data dari sumber-sumber lain, baik berupa wawancara bersama para ahli maupun literatur yang mendukung pembahasan. Selanjutnya, data penelitian ini dianalisis dengan menggunakan metode deskriptif-interpretatif.'

\section{Kualitas Pribadi Konselor}

Kompetensi pribadi adalah salah satu kompetensi yang harus dimiliki oleh konselor profesional. Kompetensi tersebut dicerminkan pada sikap dan perilaku pribadi yang beriman dan bertaqwa kepada Tuhan Yang Maha Esa, menghargai dan menjunjung tinggi nilai-nilai kemanusiaan, individualitas dan kebebasan memilih, menunjukkan integritas dan stabilitas kepribadian yang kuat dan menampilkan kinerja berkualitas tinggi. ${ }^{10}$ Oleh karena itu, kompetensi pribadi konselor merupakan salah satu kompetensi yang harus dimiliki oleh seorang konselor yang berkaitan dengan tingkah laku pribadi konselor dengan menampilkan nilai-nilai luhur dalam hubungan konseling dan dalam perilaku kehidupan sehari-hari di masyarakat.

Dalam salinan Permendiknas No. 27 Tahun 2008 tentang Standar Kualifikasi Akdemik dan Profesional Konselor dijelaskan bahwa terdapat terdapat salah satu kompetensi konselor yang harus dimiliki, yaitu kompetensi kepribadian beserta beberapa kompetensi inti dan indikator kompetensi

\footnotetext{
${ }^{8}$ S. Arikunto, Prosedur Penelitian: Suatu Pendekatan Praktek. (Jakarta: Rineka Cipta, 1993), 131.

9 Deskripsi merupakan proses penjabaran dan penguraian data-data yang ada atau menerjemahkan sedimikian rupa sehingga mendapatkan gambaran yang lebih jelas, Sedangkan interpretasi adalah proses pemaknaan dan penafsiran dari data yang telah dideskripsikan sebelumnya untuk memperoleh pemahaman yang lebih mendalam dan komprehensif dengan tetap bertumpu pada evidensi objekti. Lihat: Sudarto, Metodelogi Penelitian Filsafat (Jakarta: PT. Raja Grafindo Persadam 1997), 111.

10 Atmoko, Adi, Pendidikan Konselor Masa Depan. (Semarang: Proceding Profesi Konselor Masa Depan, 2014), 484.
} 
kepribadian tersebut. Pertama, beriman dan bertakwa kepada Tuhan Yang Maha Esa. Indikatornya adalah; (1) menampilkan kepribadian yang beriman dan bertakwa kepada Tuhan Yang Maha Esa; (2) konsisten dalam menjalankan kehidupan beragama dan toleran terhadap pemeluk agama lain; dan (3) berakhlak mulia dan berbudi pekerti luhur.

Kedua, menghargai dan menjunjung tinggi nilai-nilai kemanusiaan, individualitas dan kebebasan memilih. Indikatornya adalah; (1) mengaplikasikan pandangan positif dan dinamis tentang manusia sebagai makhluk spiritual, bermoral, sosial, individual, dan berpotensi; (2) menghargai dan mengembangkan potensi positif individu pada umumnya dan konseli pada khususnya; (3) peduli terhadap kemaslahatan manusia pada umumnya dan konseli pada khususnya; (4) menjunjung tinggi harkat dan martabat manusia sesuai dengan hak asasinya; (5) toleran terhadap permasalahan konseli; dan (6) bersikap demokratis.

Ketiga, menunjukkan integritas dan stabilitas kepribadian yang kuat. Indikatornya adalah; (1) menampilkan kepribadian dan perilaku yang terpuji (seperti berwibawa, jujur, sabar, ramah, dan konsisten); (2) menampilkan emosi yang stabil; (3) peka, bersikap empati, serta menghormati keragaman dan perubahan; dan (4) menampilkan toleransi tinggi terhadap konseli yang menghadapi stres dan frustasi.Keempat, menampilkan kinerja berkualitas tinggi. Indikatornya adalah; (1) menampilkan tindakan yang cerdas, kreatif, inovatif, dan produktif; (2) bersemangat, berdisiplin, dan mandiri; (3) berpenampilan menarik dan menyenangkan; dan (4) berkomunikasi secara efektif. ${ }^{11}$

Di sisi lain, Cavanagh merumuskan kualitas pribadi konselor ideal yang ditandai dengan karakter-karakter seperti (1) pemahaman tentang diri sendiri, (2) kondisi psikologis konselor yang baik, (3) dapat dipercaya, (4) kejujuran, (5) memiliki kekuatan untuk mengayomi konseli, (6) kehangatan, (7) pendengar yang aktif, (8) kesabaran, (9) kepekaan, kebebasan, dan (10) kesadaran menyeluruh. ${ }^{12}$ Selain itu, Brammer mendukung pentingnya kualitas pribadi konselor sebagai faktor yang menentukan keefektifan layanan bimbingan dan konseling. Kemudian, Brammer mendeskripsikan kualitas pribadi yang harus dimiliki oleh konselor yang terdiri dari (1) kesadaran akan diri dan nilai, (2) kesadaran akan nilai dan budaya, (3) kemampuan menganalisis kemampuan yang dimiliki oleh konselor sendiri, (4) kemampuan untuk melayani sebagai

11 Peraturan Menteri Pendidikan Nasional Republik Indonesia (Permendiknas). Nomor 27 Tahun 2008 Tentang Standar Kualifikasi Akademik dan Kompetensi Konselor.

${ }^{12}$ Cavanagh, ME, The Counseling Experience: A Theoretical Approach. (California: Brooks/Cole Publishing Company, 1982), 211-212. 
teladan dan pemimpin, atau orang yang memiliki pengaruh, (5) altruisme, (6) pengahayatan etnik yang kuat, dan (7) tanggung jawab. ${ }^{13}$

Dalam konteks keindonesiaan, secara khusus Fuad menguraikan beberapa karakteristik pribadi ideal konselor yaitu, (1) beriman dan bertakwa; (2) menyenangi manusia; (3) komunikator yang terampil; (4) pendengar yang baik; (5) memiliki ilmu yang luas, terutama tentang wawasan tentang manusia dan sosial-budaya; (6) menjadi narasumber yang kompeten; (7) fleksibel, tenang, dan sabar; (8) menguasai keterampilan atau teknik; (9) memiliki intuisi; (10) memahami etika profesi; (11) respek, jujur, asli, menghargai, dan tidak menilai; (12) empati, memahami, menerima, hangat, dan bersahabat; (13) fasilitator dan motivator; (14) emosi stabil; pikiran jernih, cepat, dan mampu; (15) objektif, rasioanl, logis, dan konkrit; dan (16) konsisten dan tanggung jawab. ${ }^{14}$

\section{Nilai-nilai Pesantren}

Sejak awal pendidikan pesantren sejatinya lebih menekankan pentingnya akhlak daripada intelektualitas belaka. Secara keseluruhan, pendidikan yang diterapkan di pesantren berorientasi pada pembentukan karakter santri. Dalam membentuk karakter tersebut, pendidik dalam hal ini konselor memiliki peranan yang sangat menentukan terhadap keberhasilannya. Peranannya dalam melakukan proses internalisasi nilai-nilai positif ke dan di dalam diri konseli (santri) tidak bisa digantikan oleh metode, teknik, dan media pendidikan secanggih apapun. Hal ini karena pendidikan di pesantren menjadikan sosok pribadi konselor sebagai teladan hidup (living mode) yang setiap perilaku dan sikapnya menjadi cerminan dalam kehidupannya. Maka penting bagi konselor di pesantren untuk memiliki kualitas pribadi yang sesuai dengan prinsip dan nilainilai pesantren.

Sebagai konselor pesantren, penting untuk menggali kembali nilai-nilai Islam sebagai pijakan pesantren yang mengatur profetik dan prosefionalisme konselor. Rasulullah saw. sebagai sosok pendidik tauladan dalam pendidikan Islam. Beliau mengemban misi mulia yang tercermin dalam Qs. Al-Jumu'at: 2 yang menjelaskan bahwa tugas Rasulullah saw. antara lain adalah membacakan ayat-ayat Allah swt, menyucikan, dan mengajar manusia. Sebagai sosok teladan, beliau tidak hanya sekedar membacakan atau menyampaikan, tetapi juga menyucikan, yaitu membersihkan jiwa dan mengembangkan kepribadian. Sedangkan mengajar adalah menyampaikan pengetahuan kepada santri (konseli) yang berkaitan dengan tugas-tugas penciptaan manusia, yakni menjadi khalifah (Qs. Al-Baqarah: 31).

\footnotetext{
${ }^{13}$ Brammaer, LM. The Helping Relathionship Process and Skills. (New Jersey: Prentice Hall, 1979), 173.

${ }^{14}$ Fuad, M, Kualitas Pribadi Konselor: Urgensi dan Pengembangannya. (Komunika: Jurusan Dakwah STAIN Purwokerto, Vol. 4 No. 2 Juli-Desember 2009), 247-254.
} 
Dalam pendidikan Islam, peranan pendidik (konselor) mendapatkan penghargaan yang tinggi dalam Islam. Imam Al-Ghazali memaparkan argumentasi rasional mengapa profesi pendidik (konselor) lebih mulia dibandingkan dengan profesi lainnya. "Keutamaan sebuah profesi atau pekerjaan bisa dilihat dari objek tugas profesinya. Seorang tukang emas dipandang lebih mulia jika dibandingkan dengan tukang tembaga, karena emas lebih mulia daripada tembaga. Seorang pendidik lebih tinggi kedudukannya dibandingkan dengan profesi lainnya, karena yang menjadi objek sasaran tugasnya adalah yang paling berharga dalam diri manusia, yaitu hatinya, sedangkan manusia adalah makhluk paling mulia. Itulah sebabnya, profesi pendidik merupakan profesi paling mulia satu tingkat di bawah kenabian". ${ }^{15}$

Rasulullah saw. sebagai sosok utama tauladan, pendidikan di pesantren juga merujuk pada para ulama terdahulu (imam aswaja) sebagai prinsip dalam mengembangkan kualitas pribadi pendidiknya (konselor). Beberapa di antaranya adalah pandangan Al-Ghazali yang dituangkan dalam karyanya Ibya' Ulumuddin dan Ayyubal Walad menjelaskan bahwa pribadi pendidik (1) bersikap lembut dan kebapakan terhadap anak didik, (2) tidak kikir dalam memberikan nasihat dan bimbingan akhlak, (3) mampu menjadikan dirinya sebagai teladan bagi para santrinya. Apa yang dikatakannya sesuai dengan apa yang diperbuatnya, (4) memahami karakteristik santri dengan cara mendalami kejiwaan mereka. Dalam pandangannya, setiap anak memiliki perbedaan kemampuan. Oleh karena itu, dengan memahami perbedaan itu akan semakin mempererat hubungan kemanusiaan (ash-sbilab al-insaniyab) antara pendidik dan santrinya, dan (5) menerapkan strategi pembelajaran yang berbasis "permainan" kepada santri yang masih anak-anak.

Konsep sosok pendidik yang ideal menurut Syaikh Al-Zarnuji dalam karyanya kitab Ta'lim Mutallim diantaranya adalah (1) keikhlasan dalam menjalankan tugasnya merupakan kunci utama kesuksesan dalam menjalankan tugas belajarnya, (2) zuhud karena mencari ridho Allah swt., (3) berpengalaman karena pendidik memerankan seorang pemimpin dan pembimbing dalam proses belajar, (4) penyabar yang dapat menerima segala hal dengan sikap santun dan sopan, (5) memiliki sikap murah hati terhadap santri, (6) memiliki sikap tegas dan terhormat menjadi keistimewaan yang harus dimiliki oleh pendidik, (7) memiliki adab yang baik, (8) kemampuan mengayomi dengan menyangi santrinya, (9) memahami karakter santrinya secara keseluruhan, dan (10) memiliki keilmuan ('alim) yang kompeten. ${ }^{16}$

Sedangkan menurut KH. Hasyim Asyari karakteristik pendidik ideal adalah (1) selalu berusaha mendekatkan diri kepada Allah swt., (2) memiliki rasa takut kepada Allah swt., (3) memiliki sikap tenang dalam segala hal, (4) berhati-

15 Al-Ghazali, Ihya' Ulumuddin Jilid 1 (Kairo: Matba'ah Shabih, tt), 49.

${ }^{16} \mathrm{Al}$-Zarnuji, Ta'limul Muta'allim (Semarang: CV. Toha, 1995), 23. 
hati atau wara' dalam perkataan maupun tindakan, (5) tawadhu' atau rendah hati, (6) selalu berpodaman pada prinsip, (7) menghindari pekerjaan yang dapat merendahkannya, (8) menegakkan sunnah, (9) bergaul dan bersosialisasi secara ramah, (10) menyucikan jiwa, (11) terbuka untuk umum, baik saran maupun saran atau kritik, (12) selalu mengambil ilmu dari orang lain yang tidak diketahuinya, dan (13) meluangkan waktu untuk menulis buku. ${ }^{17}$

\section{Pengembangan Kualitas Pribadi Konselor Berbasis Nilai Pesantren}

Layanan bimbingan dan konseling yang efektif ditentukan oleh kualitas pribadi konselor yang mendukung terhadap kinerjanya sebagai konselor yang profesional. Efektivitas layanan yang diberikan nampak pada perubahanperubahan yang terjadi pada konseli setalah melakukan layanan bimbingan dan konseling. Upaya internalisasi nilai-nilai kearifan lokal (local wisdom) dalam merumuskan konsepsi kualitas pribadi konselor menjadi penting dilakukan. Salah satu pendekatan yang dapat digunakan untuk merumuskan kualitas pribadi konselor berbasis kearifan lokal adalah rumusan kualitas pribadi konselor yang digali dari nilai-nilai pesantren, sebab pesantren merupakan lembaga pendidikan tertua dan dianggap sebagai produk asli Indonesia yang mengandung nilai-nilai keislaman dan sarat dengan nilai-nilai lokalitas keindonesiaan.

Konselor profesional adalah konselor yang selalu berupaya untuk mengembangkan diri. Konselor selalu menjadi pembelajar dan pengembang diri yang taat asas pada perbaikan kemampuan dan keterampilan, demi memenuhi panggilan tugas-tugas profesional. ${ }^{18}$ Selanjutnya, salah satu pengembangan diri konselor dilakukan dengan menginternalisasikan sekaligus meningkatkan kualitas pribadi konselor yang sesuai dengan nilai-nilai pesantren. Terdapat beberapa nilai-nilai pesantren yang dapat diwujudkan dalam perlakuan konselor kepada konselinya, diantaranya adalah (1) ketulusan, (2) sabar, (3) tegas dan terhormat, (4) berhati-hati, (5) keterbukaan, (6) álim, (7) kasih-sayang, dan (8) adil.

Pertama, ketulusan diwujudkan pada tindakan konselor yang menunjukkan perilaku konselor yang mampu menerima konseli seutuhnya (tanpa syarat) yang ditunjukkan dengan sikap yang perhatian, kehangatan, dan penghargaan. Sikap tersebut selaras dengan konsep karaktertistik pribadi ideal konselor menurut pandangan Carl Rogers, yaitu unconditional positive regard yang berarti sikap konselor yang menerima konseli sepenuhnya, sikap konselor yang menghargai konseli tanpa syarat, dan sikap konselor yang menghormati konseli

\footnotetext{
${ }^{17}$ Asy'ari, H. Pendidikan ala Pesantren: Terjemahan Adaptif Kitab Adabul 'Alim wa Muta'allim (Malang: Lintera Ulul Albab, 2013), 48.

${ }^{18} \mathrm{ME}$. Wibowo,Konselor Masa Depan (The Future Counselor) (Semarang: Proceeding Profesi Konselor Masa Depan, 2014), 38.
} 
seutuhnya tanpa memandang latar belakang konseli, baik ras, suku, budaya, dan agama. ${ }^{19}$

Kedua, kesabaran tampak pada sikap konselor yang ramah lemah lembut dalam melayani konseli sehingga konselor lebih banyak mendengarkan daripada berbicara. Ketiga, tegas dan terhormat diwujudkan pada perbuatan konselor yang bijak dan memungkinkan konseli senang mengungkapkan segala harapan, pandangan dan segala persoalan yang dihadapinya.Keempat, berhati-hati yang diwujudkan pada sikap konselor yang objektif dan solutif membantu persoalan yang dialami konseli sehingga konselor mampu memahami kesulitan dan tantangan yang dialami dan dirasakan konseli.

Kelima, keterbukaan diwujudkan pada sikap dan perilaku konselor yang siap memberikan pilihan-pilihan pada klien untuk mengungkapkan keinginan, kehendak, harapan serta pandangannya tentang orang lain. Selain itu, sikap keterbukaan konselor ini dapatdiwujudkan pada sikap yang senantiasa melakukan upaya kontekstualisasi dalam merespon berbagai persoalan. Sikap keterbukaan dalam layanan bimbingan dan konseling berkaitan dengan istilah intentionalitiy. ${ }^{20}$ Sikap dinamis atau fleksibelitas mengharuskan konselor tidak terlalu kaku dalam melakukan layanan bimbingan dan konseling. Konselor seharusnya mampu bersikap peka, responsif, dan pro-aktif terhadap perubahanperubahan pada diri konseli, baik sikap, persepsi, dan ekspektasi konseli terhadap konselor.

Keenam, alim diwujudkan pada perilaku konselor yang tampil sebagai manusia bijaksana yang siap menghadapi konseli dan tidak terlalu banyak tanya yang dapat menumbuhkan rasa percaya konseli pada kemampuan konselor. Selain itu, sikap alim juga dapat artikan dengan sikap memiliki pengetahuan yang mampuni (kompeten). Cavanagh mengemukakan pandangannya terkait dengan karakteristik kepribadian yang harus dimiliki konselor, salah satunya adalah kompeten (competence) yang berarti bahwa konselor harus memiliki kualitas fisik, intelektual, emosional, sosial, dan moral sebagai pribadi yang berguna. ${ }^{21}$

Ketujuh, kasih sayang ditunjukkan pada perbuatan konselor yang turut prihatin akan keadaan konseli yang mendambakan kasih sayang dan empati, sehingga klien luput dari kealpaan, kelalaian, keras kepala, dan reaksi negatif lainnya.Kedelapan, adil diwujudkan pada perbuatan konselor membantu konseli

\footnotetext{
${ }^{19} \mathrm{MZH}$. Annajih, Karakteristik Pribadi Ideal Konselor dalam Perspektif Aswaja an-Nabdliyah (Kajian Hermeneutik Gadamer Terbadap Teks Khittah an-Nabdliyah). (Tesis Pascasarjana Univ. Nageri Malang, 2016), 90.

20 Mappiare, AT, Meramu Model Konseling Berbasis Budaya Nusantara: KIPAS (Konseling Intensif Progresif Adatif Struktur) (Malang: Naskah Pidato Pengukuhan Guru Besar Universitas Negeri Malang, 2017), 74

${ }^{21}$ Mappiare, AT, Meramu Model Konseling Berbasis Budaya Nusantara: KIPAS (Konseling Intensif

Progresif Adatif Struktur) ,...80
} 
agar menciptakan keselarasan dan keseimbangan, terpelihara dari keganjilan, kekeliruan, kedzaliman dan kebingungan.

\section{Kesimpulan}

Kesimpulan dapat disarikan dari kajian yang telah diuraikan beberapa karakteristik kualitas pribadi yang perlu dimiliki seorang konselor di Indonesia yaitu sebagai berikut;(1) beriman dan bertakwa; (2) menyenangi manusia; (3) komunikator yang terampil; (4) pendengar yang baik; (5) memiliki ilmu yang luas, terutama tentang wawasan tentang manusia dan sosial-budaya; (6) menjadi narasumber yang kompeten; (7) fleksibel, tenang, dan sabar; (8) menguasai keterampilan atau teknik; (9) memiliki intuisi; (10) memahami etika profesi; (11) respek, jujur, asli, menghargai, dan tidak menilai; (12) empati, memahami, menerima, hangat, dan bersahabat; (13) fasilitator dan motivator; (14) emosi stabil; pikiran jernih, cepat, dan mampu; (15) objektif, rasioanl, logis, dan konkrit; dan (16) konsisten dan tanggung jawab.

Nilai-nilai pesantren yang dapat diwujudkan pada sikap konselor di pesantren yaitu; (1) ketulusan, (2) sabar, (3) tegas dan terhormat, (4) berhati-hati, (5) keterbukaan, (6) álim, (7) kasih-sayang, dan (8) adil. Berdasarkan paparan hasil penelitian di atas terdapat beberapa saran yang peneliti ajukan diantaranya: Pertama, penelitian ini diharapkan konselor mampu meningkatkan kualitas pribadinya dalam membantu persoalan konseli sehingga mendapatkan pembelajaran dan perubahan melalui proses konseling yang efektif. Kedua, penelitian ini dapat dijadikan salah satu acuan untuk dapat mengembangkan kualitas pribadi konselor dengan berbagai pendekatan. Ketiga, konselor di pesantren diharapkan selalu berupaya untuk meningkatkan kompetensi akademik, kepribadian, dan kelilmuannya dengan landasan yang sesuai dengan nilai-nilai pesantren.

\section{Daftar Pustaka}

Al-Ghazali. (n.d.). Ihya' Ulumuddin Jilid 1. Kairo: Matba'ah Shabih, tt.

Al-Zarnuji. (1995). Ta'limul Muta'allim (Terjemahan). Semarang: CV. Toha.

Annajih, M. (2016). Karakteristik Pribadi Ideal Konselor dalam Perspektif Aswaja anNabdliyah (Kajian Hermeneutik Gadamer Terbadap Teks Khittah anNabdliyah). Tesis Pascasarjana Univ. Nageri Malang. 
Arifin, S. (14-16 2013). Potret Kualitas Pribadi Konselor Bermartabat Perspektif Konseling At-Tawazun. Prosiding Kongres XII, Konvensi Nasional XVIII ABKIN dan Seminar Internasional Konseling. , (p. 280). Bali.

Arikunto, S. (1993). Prosedur Penelitian: Suatu Pendekatan Praktek. Jakarta: Rineka Cipta.

Asy'ari, H. (2013). Pendidikan ala Pesantren: Terjemahan Adaptif Kitab Adabul 'Alim wa Muta'allim . Malang: Lintera Ulul Albab

Mappiare, A. (14-16 November 2013). "Martabat Konselor Indonesia dalam Falsafah dan Kinerja Model KIPAS: Konseling Intensif Progresif Adaptif Struktur". Prosiding Kongres XII, Konvensi Nasional XVII ABKIN dan Seminar Internasional Konseling, (p. 40). Bali.

Atmoko, A. (2014). Pendidikan Konselor Masa Depan. Proceding Profesi Konselor Masa Depan, (p. 484). Semarang.

Brammaer, L. (1979). The Helping Relathionship Process and Skills. New Jersey: Prentice Hall.

Cavanagh, M. (1982). The Counseling Experience: A Theoretical Approach. California: Brooks/Cole Publishing Company.

Corey, G. (2009). Theory and Practice of Counseling and Psychotherapy (Buku Terjemahan). Belmont, CA: Brooks/Cole.

Fuad, M. (Vol. 4 No. 2 Juli-Desember 2009). Kualitas Pribadi Konselor: Urgensi dan Pengembangannya. Komunika: Jurusan Dakwah STAIN Purwokerto, 247-254.

Mappiare, A. (2017). Meramu Model Konseling Berbasis Budaya Nusantara: KIPAS (Konseling Intensif Progresif Adatif Struktur) Naskah Pidato Pengukuban Guru Besar Universitas Negeri Malang. Malang: Universitas Negeri Malang. 
Peraturan Menteri Pendidikan Nasional Republik Indonesia (Permendiknas). Nomor 27 Tahun 2008 Tentang Standar Kualifikasi Akademik dan Kompetensi Konselor.

Sudarto. (1997). Metodelogi Penelitian Filsafat . Jakarta: PT. Raja Grafindo Persadam .

Usman, M. (2013). Pesantren Sebagai Lembaga Pendidikan Islam (Sejarah Lahir, Sistem Pendidikan, dan Perkembangannya Masa Kini) . Vol. XIV Nomor 1 Jumal Al Hikmah, 101.

Wibowo, M. (2014). Konselor Masa Depan (The Future Counselor) . Proceeding Profesi Konselor Masa Depan, (p. 38). Semarang. 